\title{
Bone repair process in calvarial defects using bioactive glass and calcium sulfate barrier ${ }^{1}$
}

\author{
Processo de reparo ósseo em defeitos experimentais de calotas cranianas frente a utilização \\ do vidro bioativo e da barreira de sulfato de cálcio
}

\author{
Roger Lanes Silveira ${ }^{I}$, Rosilene Andréa Machado"I, Carla Roberta de Siqueira Silveira ${ }^{\mathrm{III}}$, Rogério Belle Oliveira ${ }^{\mathrm{IV}}$ \\ ${ }^{\text {I }}$ Fellow PhD degree, Department of Oral and Maxillofacial Surgery and Traumatology (OMFST), Faculty of Dentistry of Porto Alegre, PUC- \\ RS, Porto Alegre. Full Professor, Department of Oral Surgery, Post-Graduate Program, PUC-MG, Belo Horizonte, Brazil. \\ ${ }^{\text {II }}$ Master, Department of OMFST, Faculty of Dentistry of Porto Alegre, PUC-RS, Porto Alegre, Brazil. \\ III MD, Intensive Pediatric Department, Santa Casa, João Paulo II and Baleia Hospitals, Belo Horizonte - MG, Brazil. \\ Iv Full Professor, Department of OMFST, Faculty of Dentistry of Porto Alegre, PUC-RS, Porto Alegre, Brazil.
}

\begin{abstract}
Purpose: To analyze bone repair process in Wistar rats' calvaria, with the use of two different biomaterials. Methods: Forty two male Wistar rats were used, and four bicortical cranial cavities were created in each animal. The cavities were filled with: bioactive glass (BG); calcium sulfate barrier (CSB); bioactive glass covered with calcium sulfate barrier (BG/CSB); and autogenous blood clot (control). The animals were euthanized 7, 14, 21, 30, 60, 90, e 120 days after surgery. The scalps were removed and submitted to a routine process for histological preparation: staining with Haematoxylin and Eosin (HE). Results: The BG was not completely resorbed; however, after 60 days, a decrease in size as well as a change in the morphological granule were observed. CSB was not observed in the last group (after 120 days). Conclusions: In Wistar rat calvaria bioactive glass, in an isolated form, negatively interfered in the bone repair process; the calcium sulfate barrier, in an isolated form, presented the capacity to maintain space, allowing the flow of osteogenic cells; the bioactive glass covered with calcium sulfate barrier association presented a better osteoconductive capacity when compared to isolated materials; calcium sulfate barrier was completely resorbed after 90 days; control cavities did not completely heal until 120 days after surgery.
\end{abstract}

Key words: Bone Substitutes. Bone Regeneration. Calcium Sulfate. Skull. Rats.

\section{RESUMO}

Objetivo: Analisar o processo de reparo ósseo em calotas cranianas de ratos Wistar, frente ao uso de diferentes biomateriais. Métodos: Foram quatro cavidades, bicorticais, nas calotas cranianas de quarenta e dois ratos Wistar machos. As cavidades foram preenchidas com: vidro bioativo (VB); barreira de sulfato de cálcio (BSC); vidro bioativo coberto com barreira de sulfato de cálcio (VB/BSC); coágulo sangüíneo (controle). Os animais foram mortos aos 7, 14, 21, 30, 60, 90 e 120 dias após a cirurgia. As calotas foram removidas e submetidas ao processo de rotina para confecções de lâminas coradas com Hematoxilina e Eosina (HE). Resultados: O VB não foi totalmente reabsorvido, contudo, a partir dos 60 dias, observaram-se alterações no tamanho e forma dos grânulos. A BSC não foi observada no último grupo (120 dias). Conclusões: Em calotas cranianas de ratos Wistar, o vidro bioativo na forma isolada interferiu negativamente no processo de reparo ósseo. A barreira de sulfato de cálcio na forma isolada apresentou a capacidade de manutenção do espaço preenchido, permitindo a migração de células osteogênicas. A associação vidro bioativo coberto com barreira de sulfato de cálcio apresentou uma maior capacidade osteocondutora quando comparada aos materiais nas formas isoladas. A barreira de sulfato de cálcio foi totalmente reabsorvida após 90 dias; As cavidades utilizadas como controle não cicatrizaram completamente até o período de 120 dias.

Descritores: Substitutos Ósseos. Regeneração Óssea. Sulfato de Cálcio. Crânio. Ratos.

${ }^{1}$ Research performed at the Oral and Maxillofacial Surgery and Traumatology Center, Department of OMFST, Pontifical Catholic University of Rio Grande do Sul (PUC-RS), Porto Alegre, Brazil.

\section{Introduction}

Bone tissue has a primordial and essential function in the metabolism of calcium, as it is the largest reserve of calcium in the organism and serves as ancor for the origin and insertion of muscles, besides performing the function of protecting prime structures ${ }^{1}$. The need for surgical procedures in bones generates, at times, a more complex repair of the organism².
For this reason, bone repair is a highly studied theme and research has attempted to develop new materials to recuperate and/or maintain bone volume and quantity in regions where their anatomic formations were lost. Materials for implantation can be divided into four groups: autologous, homologous, heterologous, and alloplastic ${ }^{3}$.

The autogenous graft is considered the best and most widely accepted material for the treatment of bone defects. 
Nevertheless, the need for additional surgery in the donor's area, in contrast with the receptor's area, becomes an inconvenience for many patients who do not accept the intervention in other regions of the body ${ }^{4,5}$.

Substitutes for implantation in the organism should contain specific characteristics, such as: it shoud be biocompatible, it should be neither alergenic nor carcinogenic, it shoud be resistant to deformity, and it should or should not be resistant to resorption according to the desired application ${ }^{6}$.

The introduction of alloplastic materials as substitutes for bone grafts, including bioactive glass, first occurred in the 70 's, together with xenogenic and allogenic materials. The bone glass available in the market is composed of silicon dioxide $\left(\mathrm{SiO}_{2}\right)$, calcium oxide $(\mathrm{CaO})$, sodium oxide $\left(\mathrm{Na}_{2} \mathrm{O}\right)$, and phosphate pentoxide $\left(\mathrm{P}_{2} \mathrm{O}_{5}\right)$; it possesses biocompatibility with body tissues, allows for bone migration and the colonization of osteogenic cells on its surface, in addition to presenting a greater capacity for linkage to the bone and soft tissues, when compared to other alloplastic materials ${ }^{3,5}$. The components of disassociation of the material support the formation of new bone, and its glass particles have the capacity of incorporating themselves within the new bone ${ }^{7}$.

Calcium sulfate is considered a secure material because it is absorbable, malleable, easily manipulated, and it can be used as a filler or agglutinant agent of other bone implants, in addition to presenting low cost. It can be used as a physical barrier, allowing for the osteopromotion mechanism as well as carrying out bone regeneration in controlled clinical trials and in studies with animals ${ }^{8,9}$. One of the main advantages associated with calcium sulfate is its in vitro biocompatibility and its tolerance to in vivo gengival tissues ${ }^{10}$.

Although reports have documented positive results obtained with the use of the afore mentioned materials, there is also a demand for studies which would demonstrate the histological effects of calcium sulfate, when associated with bioglass and when used as a barrier, in the treatment of bone defects. The present study aims at analyzing the microscopic characteristics of the bone repair process in defects created in the scalps of rats, filled with bioactive glass (BG), calcium sulfate barrier (CSB), bioactive glass covered with calcium sulfate (BG/CSB), and autogenous blood clot (control). The assessment was car- ried out using histological analysis of slides stained with haematoxylin and eosin, put together from the pieces collected after the death of the animals, in predetermined periods of time beginning with the date of the first insertion of the materials.

\section{Methods}

Forty-two male Wistar rats, weighing 300g, were used as animal models. A single surgical procedure was performed to create four calvarial $2 \mathrm{~mm}$ defects in the parietal bone. The first bone defect was filled with isolated bioactive glass (BG) (PerioGlas ${ }^{\circledR}$ ), the second was filled with calcium sulfate barrier (CSB) $\left(\right.$ Capset $\left.^{\circledR}\right)$, the third was filled with bioactive glass covered with calcium sulfate barrier (BG/CSB), and the fourth remained unfilled (control). Six animals of each group were euthanized $7,14,21,30,60,90$, and 120 days after surgery.

The animals were anesthetized with an intramuscular injection of ketamine hydrochloride $(0,05 \mathrm{ml} / 100 \mathrm{~g})$ and xylazine $(0,025 \mathrm{ml} / 100 \mathrm{~g})$. The scalps were shaved and disinfected; the cranium was accessed via coronal incision and subperiosteal reflection. A low-speed handpiece with a n. ${ }^{\circ} 10$ bur ( $2 \mathrm{~mm}$ of diameter), under physiological saline solution ( $0.9 \%$ sodium chloride) irrigation, was used, taking care not to damage the meninges. Care was taken to guarantee at least $3 \mathrm{~mm}$ distance between the defects.

The cavities were filled with the respective materials, with one cavity destined to the control group containing blood clot (Figure 1A). The soft head tissues were sutured with simple interrupted stitches (nylon 4-0). The animals were put into cages with three specimens each, kept in climatized conditions, fed with specific animal food and water ad libitum until the date set for the euthanasia of each group.

After the respective dates, the specimens were euthanized in a carbon gas chamber. The pieces were removed with a $\mathrm{n}^{\circ} 702$ bur, under irrigation with physiological saline solution, with a safety margin of at least $4 \mathrm{~mm}$ from the borders of the cavities (Figure 1B). The pieces were stored in 10\% formaldahyde solution for 24 hours and, after that, they were submitted to the routime process of slide preparation with $6 \mu \mathrm{m}$ sections, stained with Haematoxylin e Eosin (HE), to be analyzed under an optical microscope (Figure 1C).

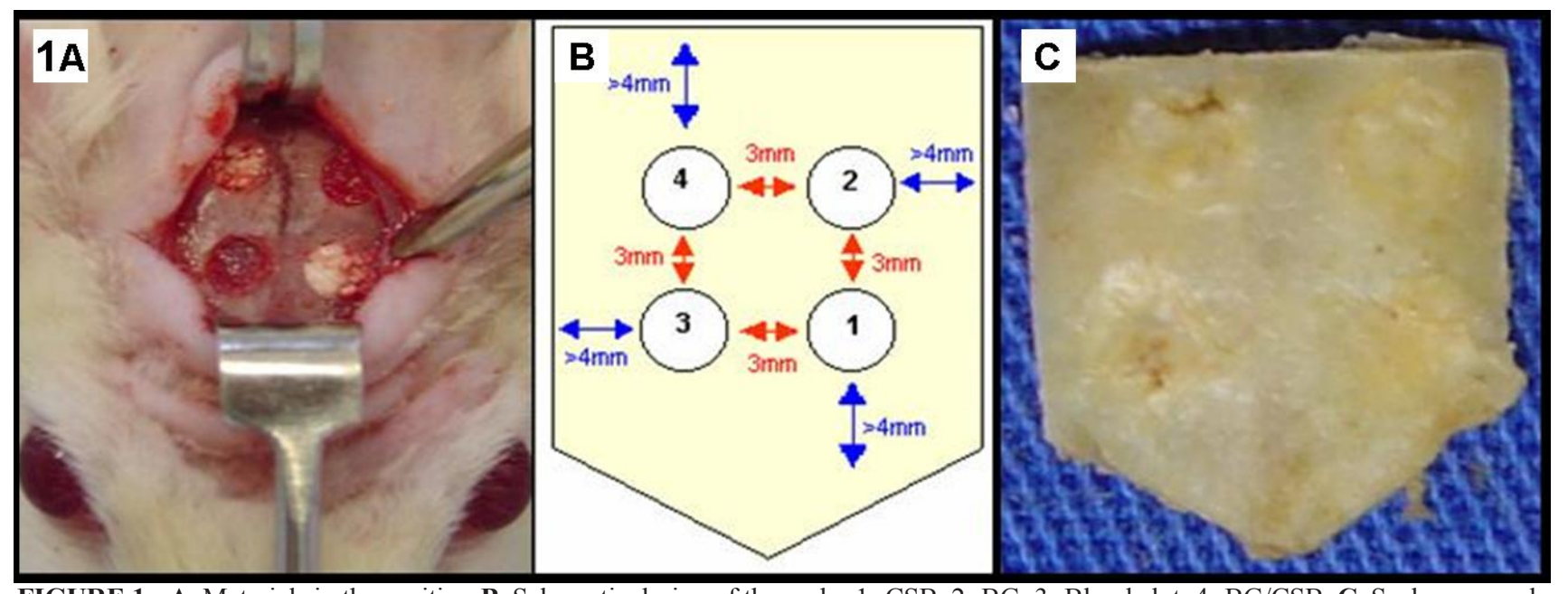

FIGURE 1 - A. Materials in the cavities. B. Schematic design of the scalp: 1- CSB, 2- BG; 3- Blood clot; 4- BG/CSB. C. Scalp removed. 


\section{Results}

Items microscopically analysed included: presence of inflammatory infiltrate, internal and external cortical formation, presence of filler material in the cavity, bone formation in the margins of the cavity, bone formation in the center of the cavity, and presence of giant cells.

Bone formation in the internal and external cortices was considered upon identification of any neoformed projection of these structures into the internal region of the created defect. In the cavities where there was bone growth in the "margins", occupying nearly $2 / 3$ of the bone defect, internal and external cortices were also considered. The item "viewing of giant cells" was considered absent when up to four giant cells appeared and present when five or more cells appeared.

The cavities were microscopically analyzed at $40 \mathrm{X}$ and 100X magnification; nevertheless, there was no significant statistical difference $(p \leq 0,05)$ between these magnifications in the majority of cases, which is in accordance with the McNemar test. The results are shown in figures 2 to 8 and in the representative table, regarding the presence of the analyzed items, at 40X and 100X magnification, when applicable (Table 1). The viewing of gigantic cells could only be observed at 400X magnification.

TABLE 1 - Percentage of items microscopically analyzed

\begin{tabular}{|c|c|c|c|c|c|c|c|c|}
\hline \multicolumn{9}{|c|}{ Presence of Inflammatorv Infiltrate: $40 \mathrm{X}$} \\
\hline Treatment & 7 davs & 14 davs & 21 davs & 30 davs & 60 davs & 90 davs & 120 davs & Total \\
\hline $\mathrm{CSB}$ & $6(100 \%)$ & $6(100 \%)$ & $1(17 \%)$ & - & - & - & - & $13(31 \%)$ \\
\hline $\begin{array}{l}\text { CONTROL } \\
\text { BG }\end{array}$ & $\begin{array}{l}6(100 \%) \\
6(100 \%)\end{array}$ & $\begin{array}{c}5(83 \%) \\
6(100 \%)\end{array}$ & $1(17 \%)$ & $\overline{-}$ & $\overline{-}$ & - & - & $11(26 \%)$ \\
\hline $\mathrm{BG} / \mathrm{CSB}$ & $6(100 \%)$ & $5(83 \%)$ & $3(50 \%)$ & - & - & - & - & $\frac{14(33 \%)}{51}$ \\
\hline \multicolumn{8}{|c|}{ Formation of Internal Cortex: $40 \mathrm{X}$} & 51 \\
\hline CSB & - & $5(83 \%)$ & $6(100 \%)$ & $5(83 \%)$ & $6(100 \%)$ & $6(100 \%)$ & $6(100 \%)$ & $34(81 \%)$ \\
\hline CONTROL & - & $4(67 \%)$ & $6(100 \%)$ & $5(83 \%)$ & $6(100 \%)$ & $6(100 \%)$ & $6(100 \%)$ & $33(78 \%)$ \\
\hline BG & - & $6(100 \%)$ & $6(100 \%)$ & $6(100 \%)$ & $5(83 \%)$ & $6(100 \%)$ & $6(100 \%)$ & $35(83 \%)$ \\
\hline $\mathrm{BG} / \mathrm{CSB}$ & - & $6(100 \%)$ & $6(100 \%)$ & $5(83 \%)$ & $6(100 \%)$ & $6(100 \%)$ & $6(100 \%)$ & $35(83 \%)$ \\
\hline Total & & 21 & 24 & 21 & 23 & 24 & 24 & 137 \\
\hline \multicolumn{9}{|c|}{ Formation of External Cortex: $40 \mathrm{X}$} \\
\hline & & $1(17 \%)$ & $2(33 \%)$ & $3(50 \%)$ & $2(33 \%)$ & $2(33 \%)$ & $4(67 \%)$ & $14(33 \%)$ \\
\hline CONTROL & - & $1(17 \%)$ & $1(17 \%)$ & $3(50 \%)$ & $3(50 \%)$ & $1(17 \%)$ & $5(83 \%)$ & $14(33 \%)$ \\
\hline BG & - & - & $1(17 \%)$ & - & $1(17 \%)$ & $3(50 \%)$ & $5(83 \%)$ & $10(24 \%)$ \\
\hline BG/CSB & - & $1(17 \%)$ & $3(50 \%)$ & $2(33 \%)$ & $3(50 \%)$ & $2(33 \%)$ & $5(83 \%)$ & $16(38 \%)$ \\
\hline Total & - & 3 & 7 & 8 & 9 & 8 & 19 & 54 \\
\hline \multicolumn{9}{|c|}{ Presence of Material in Defects: $40 \mathrm{X}$} \\
\hline CSB & $5(83 \%)$ & $4(67 \%)$ & $5(83 \%)$ & $2(33 \%)$ & $1(17 \%)$ & $2(33 \%)$ & - & $19(45 \%)$ \\
\hline $\begin{array}{l}\text { CONTROL } \\
\text { BG }\end{array}$ & $\begin{array}{l}6(100 \%) \\
6(100 \%)\end{array}$ & $\begin{array}{l}6(100 \%) \\
6(100 \%)\end{array}$ & $\begin{array}{l}6(100 \%) \\
6(100 \%)\end{array}$ & $\begin{array}{l}6(100 \%) \\
6(100 \%)\end{array}$ & $\begin{array}{c}4(67 \%) \\
6(100 \%)\end{array}$ & $\begin{array}{c}5(83 \%) \\
6(100 \%)\end{array}$ & $\begin{array}{l}6(100 \%) \\
6(100 \%)\end{array}$ & $\begin{array}{c}39(93 \%) \\
42(100 \%)\end{array}$ \\
\hline BG/CSB (CSB) & $5(83 \%)$ & $4(67 \%)$ & $2(33 \%)$ & $3(50 \%)$ & - & $3(50 \%)$ & - & $17(40 \%)$ \\
\hline $\mathrm{BG} / \mathrm{CSB}(\mathrm{BG})^{\prime}$ & $6(100 \%)$ & $6(100 \%)$ & $6(100 \%)$ & $6(100 \%)$ & $6(100 \%)$ & $6(100 \%)$ & $6(100 \%)$ & $42(100 \%)$ \\
\hline Total & 28 & 26 & 25 & 23 & 17 & 22 & 18 & 159 \\
\hline \multicolumn{9}{|c|}{ Presence of Material in Defects: $100 \mathrm{X}$} \\
\hline CSB & $6(100 \%)$ & $5(83 \%)$ & $5(83 \%)$ & $4(67 \%)$ & $1(17 \%)$ & $2(33 \%)$ & - & $23(55 \%)$ \\
\hline CONTROL & $6(100 \%)$ & $6(100 \%)$ & $6(100 \%)$ & $6(100 \%)$ & $\begin{array}{c}4(67 \%) \\
6(100 \%)\end{array}$ & $5(83 \%)$ & $6(100 \%)$ & $39(93 \%)$ \\
\hline $\mathrm{BG} / \mathrm{CSB}(\mathrm{CSB})$ & $6(100 \%)$ & $6(100 \%)$ & $5(83 \%)$ & $4(67 \%)$ & $\begin{array}{c}0(100 \%) \\
-\end{array}$ & $5(83 \%)$ & $\begin{array}{c}0(100 \%) \\
-\end{array}$ & $26(62 \%)$ \\
\hline $\mathrm{BG} / \mathrm{CSB}(\mathrm{BG})$ & $6(100 \%)$ & $6(100 \%)$ & $6(100 \%)$ & $6(100 \%)$ & $6(100 \%)$ & $6(100 \%)$ & $6(100 \%)$ & $42(100 \%)$ \\
\hline Total & 30 & 29 & 28 & 26 & 17 & 24 & 18 & 172 \\
\hline \multicolumn{9}{|c|}{ Bone Formation Margin: 40X } \\
\hline CSB & - & $6(100 \%)$ & $6(100 \%)$ & $6(100 \%)$ & $6(100 \%)$ & $6(100 \%)$ & $6(100 \%)$ & $36(86 \%)$ \\
\hline CONTROL & - & $6(100 \%)$ & 6 (100\%) & $6(100 \%)$ & $6(100 \%)$ & $6(100 \%)$ & $6(100 \%)$ & $36(86 \%)$ \\
\hline BG & - & $4(67 \%)$ & $6(100 \%)$ & $6(100 \%)$ & $6(100 \%)$ & $6(100 \%)$ & $6(100 \%)$ & $34(81 \%)$ \\
\hline $\mathrm{BG} / \mathrm{CSB}$ & - & $5(83 \%)$ & $6(100 \%)$ & $6(100 \%)$ & $6(100 \%)$ & $6(100 \%)$ & $6(100 \%)$ & $35(83 \%)$ \\
\hline Total & - & 21 & 24 & 24 & 24 & 24 & 24 & 141 \\
\hline \multicolumn{9}{|c|}{ Bone Formation Center: $40 \mathrm{X}$} \\
\hline CSB & - & $1(17 \%)$ & $2(33 \%)$ & $2(33 \%)$ & $1(17 \%)$ & $1(17 \%)$ & $2(33 \%)$ & $9(21 \%)$ \\
\hline CONTROL & - & $2(33 \%)$ & $1(17 \%)$ & $2(33 \%)$ & $2(33 \%)$ & $1(17 \%)$ & $2(33 \%)$ & $10(24 \%)$ \\
\hline BG & - & - & $1(17 \%)$ & - & - & - & $1(17 \%)$ & $2(5 \%)$ \\
\hline BG/CSB & - & $1(17 \%)$ & $2(33 \%)$ & $5(83 \%)$ & $1(17 \%)$ & $2(33 \%)$ & $1(17 \%)$ & $10(24 \%)$ \\
\hline Total & - & 4 & 6 & 9 & 4 & 4 & 6 & 31 \\
\hline \multicolumn{9}{|c|}{ Bone Formation Margin: 100X } \\
\hline$\overline{C S B}$ & - & $6(100 \%)$ & $6(100 \%)$ & $6(100 \%)$ & $6(100 \%)$ & $6(100 \%)$ & $6(100 \%)$ & $36(86 \%)$ \\
\hline CONTROL & - & $6(100 \%)$ & $6(100 \%)$ & $6(100 \%)$ & $6(100 \%)$ & $6(100 \%)$ & $6(100 \%)$ & $36(86 \%)$ \\
\hline BG & - & $4(67 \%)$ & $6(100 \%)$ & $6(100 \%)$ & $6(100 \%)$ & $6(100 \%)$ & $6(100 \%)$ & $34(81 \%)$ \\
\hline BG/CSB & - & $5(83 \%)$ & $6(100 \%)$ & $6(100 \%)$ & $6(100 \%)$ & $6(100 \%)$ & $6(100 \%)$ & $35(83 \%)$ \\
\hline Total & - & 21 & 24 & 24 & 24 & 24 & 24 & 141 \\
\hline \multicolumn{9}{|c|}{ Bone Formation Center: 100X } \\
\hline CSB & - & $1(17 \%)$ & $2(33 \%)$ & $2(33 \%)$ & $1(17 \%)$ & $1(17 \%)$ & $2(33 \%)$ & $9(21 \%)$ \\
\hline CONTROL & - & $2(33 \%)$ & $1(17 \%)$ & $2(33 \%)$ & $2(33 \%)$ & $1(17 \%)$ & $2(33 \%)$ & $10(24 \%)$ \\
\hline BG & - & - & $1(17 \%)$ & - & - & - & $1(17 \%)$ & $2(5 \%)$ \\
\hline $\mathrm{PER}+\mathrm{CAP}$ & - & $2(33 \%)$ & $2(33 \%)$ & $5(83 \%)$ & $1(17 \%)$ & $2(33 \%)$ & $1(17 \%)$ & $11(26 \%)$ \\
\hline Total & - & 5 & 6 & 9 & 4 & 4 & 6 & 32 \\
\hline \multicolumn{9}{|c|}{ Presence of Giant Cells: $400 \mathrm{X}$} \\
\hline CSB & - & $2(33 \%)$ & - & - & - & - & - & $2(5 \%)$ \\
\hline $\begin{array}{l}\text { CONTROL } \\
\text { BG }\end{array}$ & $\overline{-}$ & $\begin{array}{l}1(17 \%) \\
1(17 \%)\end{array}$ & $1(17 \%)$ & $3(50 \%)$ & $1(\overline{17 \%})$ & $\overline{-}$ & $\overline{-}$ & $\begin{array}{c}1(2 \%) \\
6(14 \%)\end{array}$ \\
\hline PER+CAP & $1(17 \%)$ & $2(33 \%)$ & - & $3(50 \%)$ & $1(17 \%)$ & - & - & $7(17 \%)$ \\
\hline Total & 1 & 6 & 1 & 6 & 2 & - & - & 16 \\
\hline
\end{tabular}

* Percentage calculated in relation to the total of 42 cavities for each manner of filling. 
Using the Chi-square test $(p \leq 0,01)$, it could be observed, both at $40 \mathrm{X}$ and $100 \mathrm{X}$ magnification, that the most commonly present materials were those which fill the clot cavities and the BG cavities, in addition to the bioactive glass which fills the BG/CSB cavities. Using the same test, it could also be observed $(\mathrm{p}=0,05)$, at $100 \mathrm{X}$ magnification, that the bone formation in the central region is more present in cavities filled with blood clot, $\mathrm{CSB}$ and $\mathrm{BG} / \mathrm{CSB}$.

Present in all defects observed after 7 and 14 days postoperation were chronic infammatory infiltrate, with a significant reduction after 21 days. Fragments of bioactive glass, in

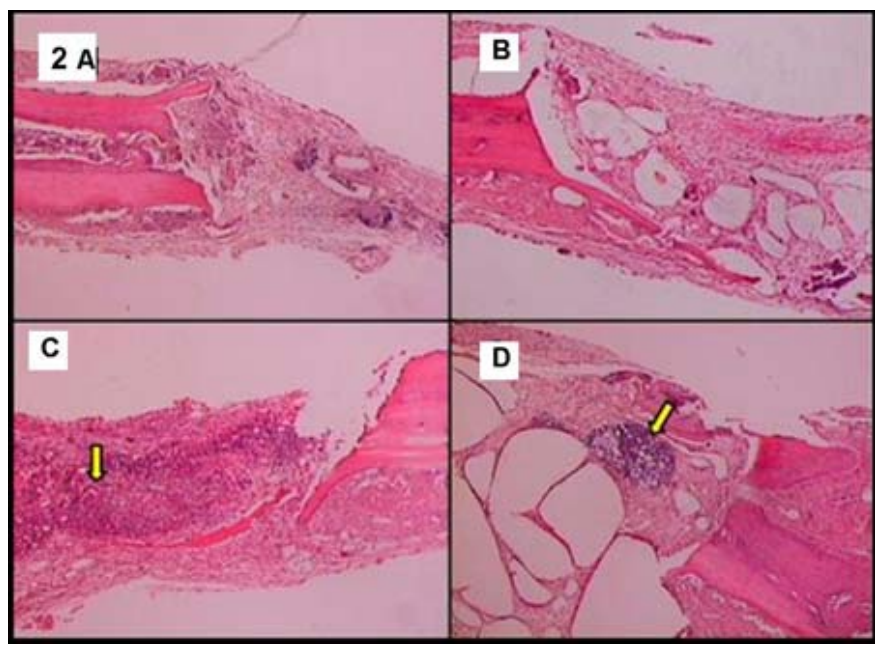

FIGURE 2 - A. Cavity filled with blood clot, after 7 days (40X). B. Cavity filled with BG, after 7 days (40X). C. Cavity filled with CSB (arrow), after 7 days (40X). D. Cavity filled with BG/CSB (arrow), after 7 days (40X)

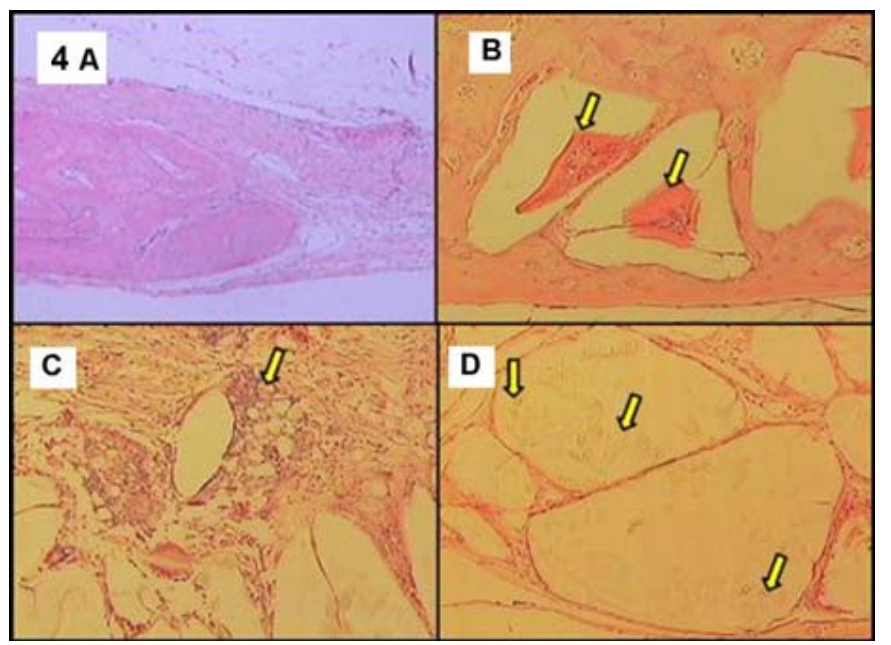

FIGURE 4 - A. Cavity filled with blood clot, after 21 days (40X). B. Tissue with bone characteristics (arrows) within the BG granules, after 21 days (100X). C. Form of CSB (arrow) in the cavity filled with $\mathrm{BG} / \mathrm{CSB}$, after 21 days (100X). D. Fragments of glass within the granule spaces (arrows), defect filled with BG/CSB, after 21 days (100X) the negative images of granules, could be seen clearly after 30 days, while after 60 days, this could be observed with an alteration in the form and size of the bioactive glass granules. At times, the CSB image could be observed in the form of dystrophic calcification. Three cavities containing CSB were completely filled with bone (one after 60 days, one after 90 days, and one after 120 days). Three cavities containing blood clots were completely filled with bone (two after 60 days and one after 90 days). After 120 days, BG ganules still existed, while the CSB could no longer be seen (Figures 2 to 8 ).

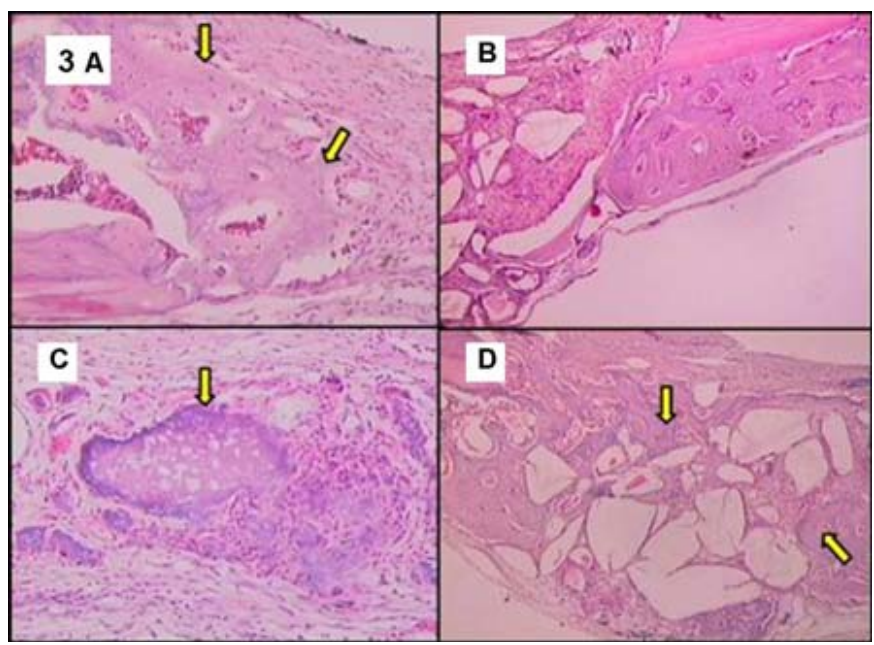

FIGURE 3 - A. Cavity filled with blood clot with bone in the margins (arrows), after 14 days (100X). B. Cavity filled with BG, after 14 days (40X). C. CSB (arrow), after 14 days (100X). D. Bone (arrows) between the granules of the cavity filled with $\mathrm{BG} / \mathrm{CSB}$, after 14 days $(40 \mathrm{X})$

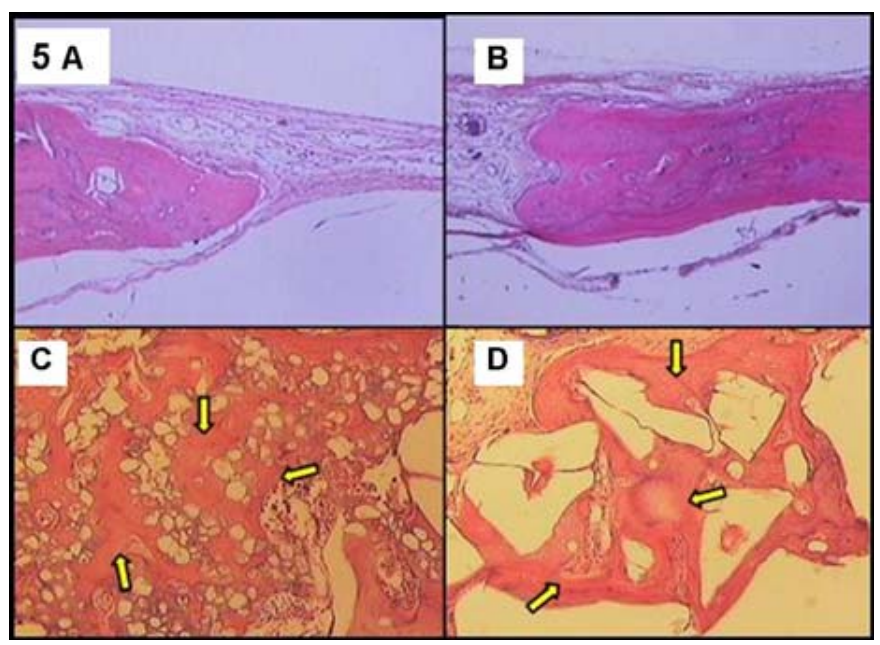

FIGURE 5 - A. Cavity filled with blood clot, after 30 days (40X). B. Cavity filled with CSB, after 30 days (40X). C. Standard bone formation in the locations where there was CSB (arrows), cavity filled with $\mathrm{BG} / \mathrm{CSB}$, after 30 days (100X). D. Bone formation around granules (arrows), cavity filled with BG/CSB, after 30 days (100X) 


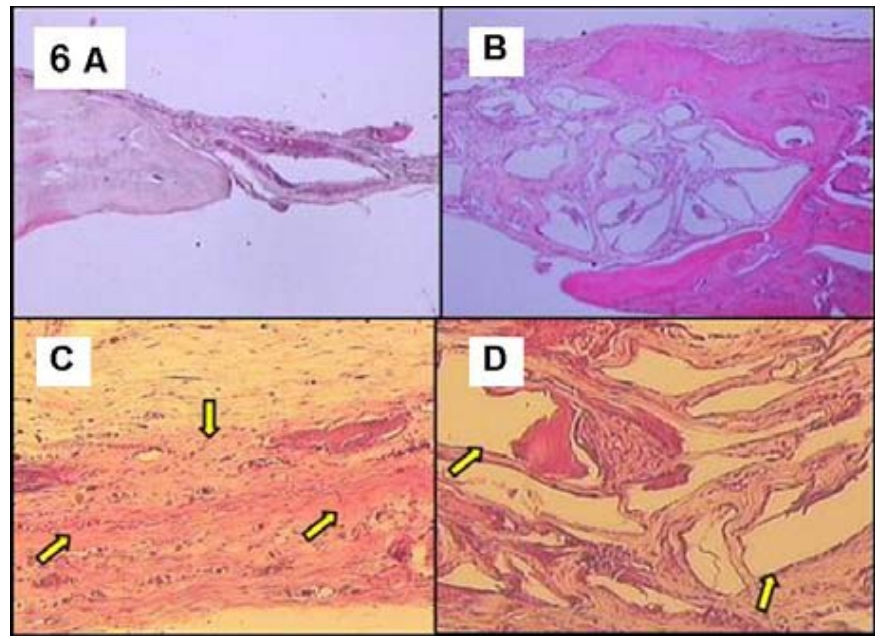

FIGURE 6 - A. Cavity filled with blood clot, after 60 days (40X). B. Change in form of granule image, cavity filled with BG, after 60 days (40X). C. Conjunctive tissue organized below the periosteal (arrows), cavity filled with CSB, after 60 days (100X). D. Change in form of granule image (arrows), cavity filled with BG/CSB, after 60 days $(100 \mathrm{X})$

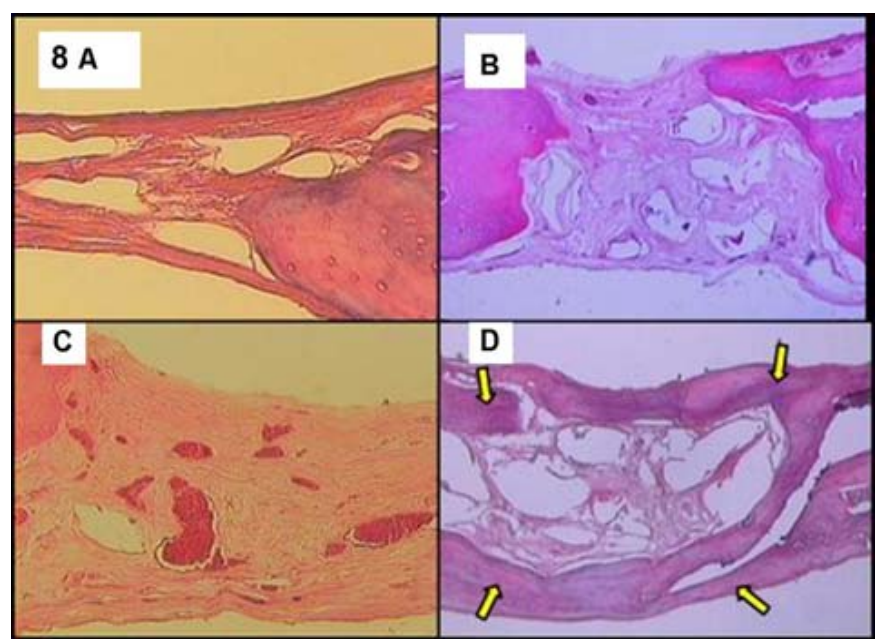

FIGURE 8 - A. Cavity filled with conjunctive guiding tissue, defect which initially contained blood clot, after 120 days (100X). B. Organized and guided conjunctive tissue around the granules, cavity filled with BG, after 120 days (40X). C. Cavity with organized and guided conjunctive tissue, cavity which initially contained CSB, after 120 days (100X). D. Formation of internal and external cortices (arrows), cavity filled with BG and locations where it also contained CSB, after 120 days (40X)

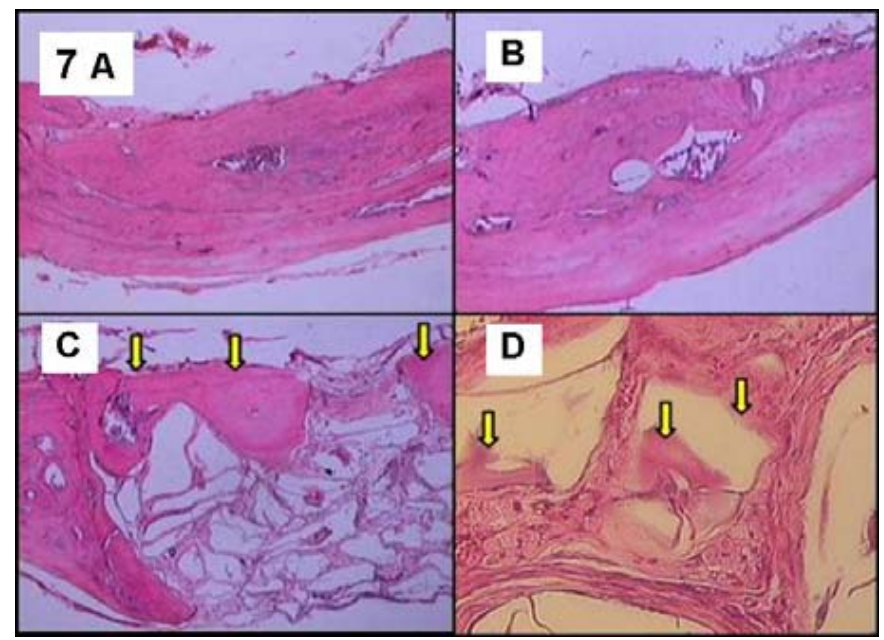

FIGURE 7 - A. Cavity filled with bone, defect which initially contained blood clot, after 90 days (40X). B. Cavity filled with bone, defect which initially contained CSB, after 90 days (40X). C. Granules of BG with alteration of form and size, formation of external cortical (arrows), cavity filled with BG/CSB, after 90 days (40X). D. Granules with alteration of form and size, formation of bone within granules (arrows), cavity filled with BG/CSB, after 90 days (100X)

\section{Discussion}

According to Schimitz and Hollinger ${ }^{11}$, the advantages of testing the defects of rat scalps is related to the number of specimens that can be used at relatively low cost, the possibility of using low quantities of filler materials, and the possibility of using particulate and gelatinous materials.

The cavities which were initially filled with blood clot (control) did not heal naturally after 120 days of observation, showing conjuctive tissue formation in $93 \%$ of the cases, coupled with a loss in the maintenance of scalp thickness. In three specimens of the control group (two after 60 days and one after 90 days), there was a complete filling of bone tissue. Pecora et al. ${ }^{8}$ cite the complete bone healing in control group cases in which defects considered critical were used.

The results obtained demonstrate that, regardless of the type of material used as a filler, the internal cortex tends to form. This fact may be related to the minimal defect generated in the internal region, favoring a more premature regeneration of this cortex. One significant percentage difference can be seen in regard to the formation of the external cortex, where the periosteal of the region was dislodged for the generation of defects. The best result for the external cortex was found in the cavities filled with $\mathrm{BG} / \mathrm{CSB}$, which possessed filler material, thus maintaining a favorable thickness while, at the same time, maintaining a coated barrier which blocked any major proliferation of non-osteogenic tissue into the internal region. The second best result was found in the control group (blood clot) and in the isolated CSB group, which presented the formation of the external cortex due mainly to bone formation in the margins, occupying approximately $2 / 3$ of the cavity dimension (in these cases, the formation of internal and external cortices were 
automatically considered). Lastly, were the BG cavities in which the greatest invasion in an internal direction of soft tissues around the particulate material was observed.

$\mathrm{Melo}^{12}$, on the other hand, using rat tibias, after 30 days, found a greater bone neoformation of the external cortex in cavities with calcium sulfate (CS) (CS and BG/CSB groups), as compared to those where only bioactive glass particulates were used. Nonetheless, the author reports better results in the formation of the external cortex in the control group (blood clot), in defects considered non-critical.

The largest percentage of bone formation in the center of the defects occurred in locations filled with BG/CSB and blood clot (24\%), with the former mainly due to the barrier protection used, while in the latter this percentage was mainly due to the high bone proliferation in the margins (approximately $2 / 3$ or more). In locations filled with CSB, there was a $21 \%$ bone formation in the central region, in addition to maintaining the thickness of the scalp. This result was still better when compared to that cavities filled with isolated $\mathrm{BG}$, where there was only $5 \%$ bone formation in this region. In three cavities, filled with isolated CSB (one after 60 days, one after 90 days, and one after 120 days), the complete filling of bone tissue could be observed. Results found herein contrast with Ruhaimi's ${ }^{13}$ findings, in his work on rabbits, where the filling of bone cavities with calcium sulfate in an isolated form is not recommended as the rate of dissolution of the material is faster than the time required for bone growth. According to Alderman ${ }^{14}$, the product does not stimulate osteogenesis; however, it does act by occupying space in an infrabony environment, generating support, and preventing soft tissues invagination until resorption gives way to new repaired tissue, in harmony with the speed of new tissue subsitution.

The Chi-square test, applied to the results obtained in the assessment of bone formation in the center of the cavities, at $100 \mathrm{X}$ magnification, demonstrates that bone formation occurred with a significant difference $(p=0,05)$ in locations initially filled with blood clot, CSB and BG/CSB. This fact illustrates that the use of BG in rat scalps, without the aid of a barrier, allowed for the proliferation of non-osteogenetic tissue among the granules. According to the findings of Pecora et al. ${ }^{8}$, the use of calcium sulfate as a barrier may impede the growth of the conjunctive tissue within the defect itself, favoring the osteopromotion mechanism.

These results suggest that the bone formation in the margins of the defects occurred regardless of the manner in which they were filled. The joining of the materials to the bone was observed, even at the $7^{\text {th }}$ day of the post-operative period, which, in the case of BG, is well-documented ${ }^{3,4,13,15,16,17,18,19,20,21}$.

$\mathrm{BG}$ remained in the defects for the entire period of the study (120 days), both in the cavities filled only with BG (100\%) as well as in the cavities filled with $\mathrm{BG} / \mathrm{CSB}$. The material was not completely substituted by bone or even conjunctive tissue, as claimed in the works of Oonishi et al. ${ }^{7}$ on the femurs of rabbits, which generated repair and were completely substituted by bone after 12 weeks. In contrast, there was a clear alteration, seen as of the $60^{\text {th }}$ day, in the morphology of the granules which appeared irregular on the surface and with reduced sizes in re- lation to the first group (after 7 days). These characteristics suggest the occurrence of the superficial dissolution of the material, described by a number of authors ${ }^{3,5,12,17,20,22}$, where a thick layer of silicon, covered with a thick layer of calcium and phosphate, is formed with a consequent collagenous attraction surrounding it.

Conjunctive tissue protrusions within BG granules were seen as of the first week. Camargo et al. ${ }^{10}$ and Huygh et $a l .{ }^{19}$ report that excavations on the surface of the granules occurred, interiorly, through the same process of dissolution which occurred on the surfaces. Phagocyte cells penetrate the most internal region through cracks, allowing the entrance of undifferentiated mesemchyme cells which will divide themselves in osteoblasts, due to the stimulus of the presence of calcium and phosphate, for bone formation ${ }^{16}$. Suggestive data on the formation of tissue with bone characteristics, in the central region of the granules, were observed on the $21^{\text {st }}$ day. This formation was also confirmed by Camargo et al. ${ }^{10}$ and Macedo et al. ${ }^{5}$. $\mathrm{Melo}^{12}$, however, affirms that they are simply remains of BG particulates covered by conjunctive tissue.

In contrast, the CSB in the present study showed a tendency toward disappearance as the periods of observance increased, indicating the resorption of the material. This material was not observed in the last group (after 120 days), but it was observed, in some cases, after 90 days. These results regarding resorption time add to those presented by Snyders Jr et al. ${ }^{9}$ who observed persistance up to 135 days; Venturini et al. ${ }^{23}$, who observed persistance of between 3 and 4 weeks; Ruhaimi ${ }^{13}$, who observed persistance between 3 and 6 weeks; Melo ${ }^{12}$, who observed persistance up to 30 days. Calcified structures, with the appearance of dystrophic calcification, found via microscopic analysis of the cavities containing CSB may in fact be due to the presence of calcium in the product compound. According to Shaffer and $\mathrm{App}^{24}$ and Ruhaimi ${ }^{13}$, the advantages of adding calcium powder to the graft is to induce calcification on locations where there are extra calcium ions, acting as a suplementary source of this element during the osteogenesis process, thus linking it directly to the host bone.

Sandberg et al. ${ }^{25}$, in their study in rats, report the presence of a large quantity of inflammatory infiltrate cells in the first week, with the use of resorbable and non-resorbable membranes, showing a drastic reduction in the second week. In the present study, the CSB, isolated or associated with BG, demonstrated, over time, a decrease in the rate of inflammatory infiltrate as well as in the rate of other filler materials

There are several scientific reports showing the presence of giant cells, microphages and lymphocytes, when bioactive glass was was used in the tissue ${ }^{12,26,27}$.

Although Sottosanti and Anson ${ }^{28}$ affirm that the use of CSB may be done in association with BG, there are few studies associating the two materials, such as those presented by Camargo et al..$^{10}$ and $\mathrm{Melo}^{12}$. There is a need for experimental works with CSB that would demonstrate its resorption time and tissue reaction to its use, in addition to studies with other animal models demonstrating the effects of the association of calcium sulfate, as a barrier or a vehicle, associated with BG. 


\section{Conclusions}

The histological findings of this study demonstrate that in infrabony $2 \mathrm{~mm}$ defects in Wistar rats calvarial defects:

1 - The bioactive glass, in an isolated form, negatively interfered in the bone repair process;

2 - The calcium sulfate barrier, in an isolated form, presented the capacity to maintain space, allowing for the migration of osteogenetic cells in its midst;

3 - The association of bioactive glass with calcium sulfate barrier (in barrier form) presented a better osteo-conductive capacity, compared to that of isolated materials;

4 -The period of complete resorption of bioactive glass is longer than 120 days, while there is a complete resorption of calcium sulfate barrier as of 90 days;

5 -Defects filled with blood clot did not heal completely within the 120 day period.

\section{References}

1. Feinberg SE, Steinberg B, Helman JI. Healing of traumatic injuries. In: Fonseca RJ, Walker RV. Oral and maxillofacial trauma. 2ed. Philadelphia: Saunders; 1997. p. 13-49.

2. Roberts WE, Garetto LP. Fisiologia e metabolismo ósseos. In: Mish CE, 1ed. Implantes dentários contemporâneos. 2ed. São Paulo: Santos; 2000. p. 225-37. 3. Nasr HF, Aichelmann-Reidy ME, Yukna RA. Bone and bone substitutes. Periodontol 2000. 1999;19:74-86.

4. Ousterhout DK, Stelnicki EJ. Plastic surgery's plastics. Clin Plast Surg. 1996;23(1):183-90.

5. Macedo NL, Matuda FS, Macedo LGS, Gonzalez MB, Ouchi SM, Carvalho YR. Bone defect regeneration with bioactive glass implantation in rats. J App Oral Sci. Rev FOB. 2004;12(2):137-43.

6. Anusavice KJ. Materiais dentários. Rio de Janeiro: Guanabara Koogan; 1998. 412p.

7. Oonishi H, Kushitani S, Yasukawa E, Iwaki H, Hench LL, Wilson J, Tsuji E, Sugihara T. Particulate Bioglass compared with hydroxyapatite as a bone graft substitute. Clin Orthop. 1997;1(334):316-25.

8. Pecora G, Andreana S, Margarone JE, Covani U, Sottosanti JS. Bone regeneration with a calcium sulfate barrier. Oral Surg Oral Med Oral Pathol Oral Radiol Endod. 1997;84:424-9.

9. Snyders RV Jr, Eppley BL, Krukowisk M, Delfino JJ. Enhancement of repair in experimenta calvarial bone defects using calcium sulfate and dextran beads. J Oral Maxillofac Surg. 1993;51:517-24.

10. Camargo PM, Lekovic V, Weinlaender M, Klokkevold PR, Kenney EB, Dimitrijevic B, Nedic M, Jancovic S, Orsini M. Influence of bioactive glass on changes in alveolar process dimensions after exodontia. Oral Surg Oral Med Oral Pathol Oral Radiol Endod. 2000;90(5):581-6.

11. Schimitz JP, Hollinger JO. The critical size defect as an experimen- tal model for craniomandibulofacial nonunions. Clin Orthop Relat Res. 1986;205:299-308.

12. Melo LGN. Avaliação do processo de reparo ósseo em cavidades cirúrgicas preenchidas com partículas de vidro bioativo associadas ou não à barreira de sulfato de cálcio: estudo histomorfométrico em tíbias de rato [mestrado]. UNESP-Araçatuba; 2003.

13. Ruhaimi AKA. Effect of adding resorbable calcium sulfate to grafting materials on early bone regeneration in osseous defects in rabbits. Int J Oral Maxillofac Implants. 2000;15(6):859-64.

14. Alderman NE. Sterile plaster of paris as an implant in the infrabony environment: a preliminary study. J Periodontol. 1969;40(1):11-3.

15. Hench LL, Splinter RJ, Allen WC. Bonding mechanisms at the interface of ceramic prosthetic materials. J Biomed Mater Res. 1971;2:117-41. 16. Schepers EJ, Ducheyne P, Ducheyne P, Barbier L, Schepers S. Bioactive glass particles of narrow size range: a new material for the repair of bone defects. Implant Dent. 1993;2(3):151-6.

17. Brink M, Lindholm TC. Bioactive sílica glass (13-93): a novel biomaterial for tissue engineering. In: Lindholm TC. Medical intelligence unit. Skeletal reconstruction and bioimplantation. Texas: Champman \& Hall; 1997. p. 53-60. 18. DeForge DH. Evaluation of Bioglass ${ }^{\circledR} /$ Perioglas $^{\mathrm{TM}}\left(\right.$ Consil $\left.^{\mathrm{TM}}\right)$ synthetic bone graft particulate in the dog and cat. J Vet Dent. 1997;14(4):141-5. 19. Huygh A, Schepers EJG, Barbier L, Ducheyne P. Microchemical transformation of bioactive glass particles of narrow size range, a 0-24 months study. J Mater Sci Mater Med. 2002;13(3):315-20.

20. Cerruti M, Morterra C. Carbonate formation on bioactive glasses. Langmuir. 2004;20(15):6382-8.

21. Shapoff CA, Alexander DC, Clarck AE. Clinical use of a bioactive glass particulate in the treatment of human osseous defects. Compend Contin Educ Dent. 1997;18(4):352-63.

22. Valerio P, Pereira MM, Goes AM, Leite MF. The effect of ionic products from bioactive glass dissolution on osteoblast proliferation and collagen production. Biomaterials. 2004;25(15):2941-8.

23. Venturini MS, Venturini MD, Hetessy LR. Sulfato de cálcio como membrana: relato de um caso clínico. Rev Odontol UNICID. 1999;11(2):131-6. 24. Shaffer CD, App GR. The use of plaster of paris in treating infrabony periodontal defects in humans. J Periodontol. 1971;42(11):685-90.

25. Sandberg E. Dahlin C. Linde A. Bone regeneration by the osteopromotion technique using bioabsorbable membranes: an experimental study in rats. J Oral Maxillofac Surg. 1993;51:1106-14.

26. Greenlee TK Jr, Beckham CA, Crebo AR, Malmorg JC. Glass ceramic bone implants. J Biomed Mater Res. 1972;6:235-44.

27. Wilson J, Pigott GH, Schoen FJ, Hench LL. Toxicology e biocompatibility of bioglasses. J Biomed Mater Res. 1981;15:805-17.

28. Sottosanti J, Anson D. Using calcium sulfate as a graft enhancer and membrane barrier. Dent Implantol Update. 2003;14(1):1-8.

\section{Acknowledgments}

We tank the Laboratório de Patologia Bucodental da PUCRS (Prof. Manoel Sant'Ana Filho, Prof. Fábio Luiz Dal Moro Maito e Cláudio Rogério Oliveira) and Centro de Microscopia e Microanálises da PUCRS.

Conflict of interest: none Financial source: none

Correspondence:

Roger Lanes Silveira

Rua Dr Sylvio Menicucci, 1065/102

30840-480 Belo Horizonte - MG Brazil

Phone: (55 31)9222-3392

rogerlanes@yahoo.com.br

Received: January 23, 2008

Review: February 19, 2008

Accepted: March 18, 2008

\section{How to cite this article}

Silveira RL, Machado RA, Silveira CRS, Oliveira RB. Bone repair process in calvarial defects using bioactive glass and calcium sulfate barrier. Acta Cir Bras. [serial on the Internet] 2008 July-Aug;23(4). Available from URL: http://www.scielo.br/acb 